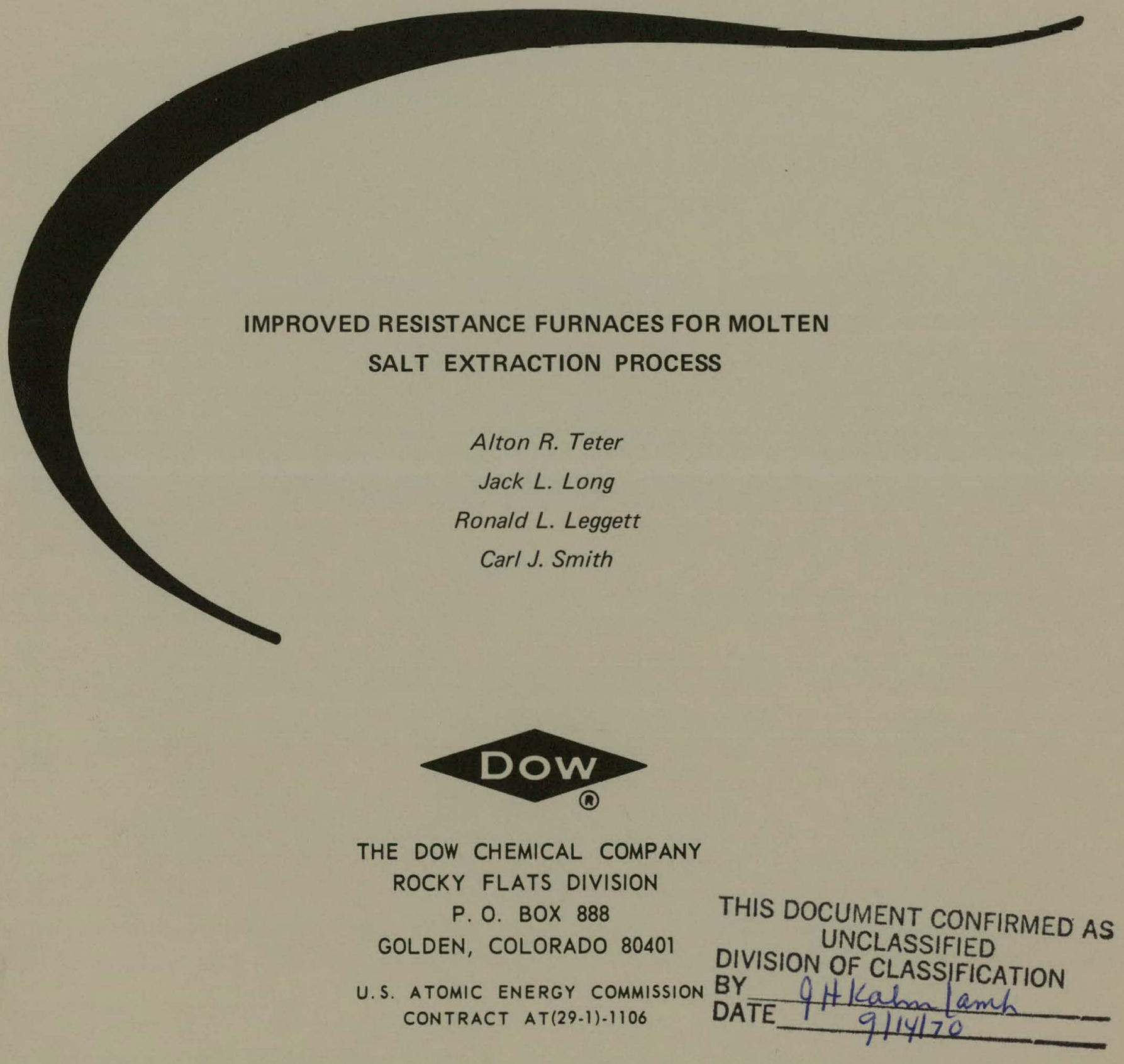




\section{DISCLAIMER}

This report was prepared as an account of work sponsored by an agency of the United States Government. Neither the United States Government nor any agency Thereof, nor any of their employees, makes any warranty, express or implied, or assumes any legal liability or responsibility for the accuracy, completeness, or usefulness of any information, apparatus, product, or process disclosed, or represents that its use would not infringe privately owned rights. Reference herein to any specific commercial product, process, or service by trade name, trademark, manufacturer, or otherwise does not necessarily constitute or imply its endorsement, recommendation, or favoring by the United States Government or any agency thereof. The views and opinions of authors expressed herein do not necessarily state or reflect those of the United States Government or any agency thereof. 


\section{DISCLAIMER}

Portions of this document may be illegible in electronic image products. Images are produced from the best available original document. 


\section{LEGAL NOTICE}

This report was prepared as an account of Government sponsored work. Neither the United States, nor the Commission, nor any person acting on behalf of the Commission:

A. Makes any warranty or representation, expressed or implied, with respect to the accuracy, completeness, or usefulness of the information contained in this report, or that the use of any information, apparatus, method, or process disclosed in this report may not infringe privately owned rights; or

B. Assumes any liabilities with respect to the use of, or for damages resulting from the use of any information, apparatus, method, or process disclosed in this report.

As used in the above, "person acting on behalf of the Commission" includes any employee or contractor of the Commission, or employee of such contractor, to the extent that such employee or contractor of the Commission, or employee of such contractor prepares, disseminates, or provides access to, any information pursuant to his employment or contract with the Commission, or his employment with such contractor.

Printed in the United States of America

Available from

Clearinghouse for Federal Scientific and Technical Information

National Bureau of Standards, U. S. Department of Commerce

Springfield, Virginia 22151

Price: Printed Copy $\$ 3.00$; Microfiche $\$ 0.65$ 


\title{
IMPROVED RESISTANCE FURNACES FOR MOLTEN SALT EXTRACTION PROCESS
}

\author{
Alton R. Teter \\ Jack L. Long \\ Ronald L. Leggett \\ Carl J. Smith
}

\section{LEGAL NOTICE}

This report was prepared as an account of work This report was propates Government. Neither sponsored by the nor the United States Atomic Energy the United States noi the United States Atomic Energy Commission, nor any of their employees, nor an theyees, their contractors, subcontractors, of their employees, makes any warranty, express or implied, or assumes any legal liability or responsibility for the accuracy, comlegal liability or responsibing of any information, apparatus, product or process disclosed, or represents that its use would not infringe privately nwned rights.

\section{THE DOW CHEMICAL COMPANY \\ ROCKY FLATS DIVISION \\ P. O. BOX 888 \\ GOLDEN, COLORADO 80401 \\ Prepared under Contract AT(29.1)-1106 \\ for the \\ Albuquerque Operotions Office \\ U. S. Atomic Energy Commission}


RFP-1513

\section{CONTENTS}

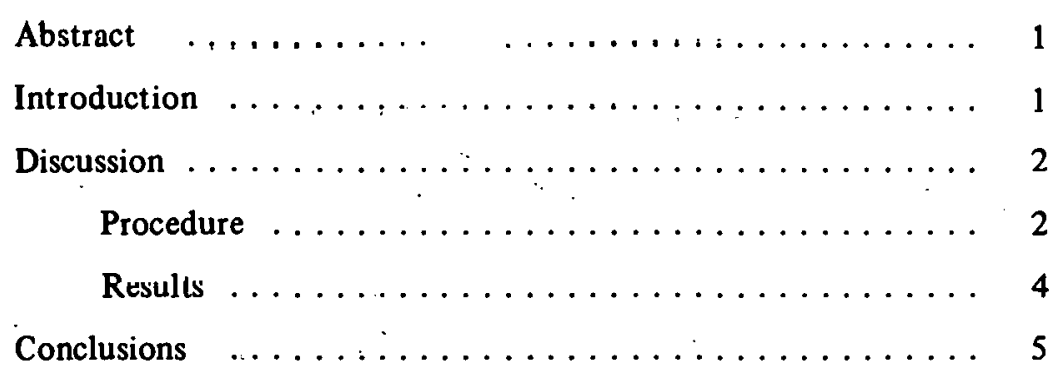




\title{
IMPROVED RESISTANCE FURNACES FOR MOLTEN SALT EXTRACTION PROCESS
}

\author{
Alton R. Teter, Jack L. Long, Ronald L. Leggett, and Carl J. Smith
}

\begin{abstract}
The high failure rate of resistance furnaces used in the process for molten salt extraction of americium from plutonium was investigated. As a result, two new furnace designs were fabricated and tested. Two of the furnaces were operated for 124 and 154 three-hour cycles to $900^{\circ} \mathrm{C}$ with no indications of element failure. In addition, it was found that the furnaces would melt the 3500-gram mock-up salt charge and maintain a melt temperature of greater than $700{ }^{\circ} \mathrm{C}$ by applying a power input of 2700 watts for two hours and then reducing the power to 1700 watts for one hour. Past production procedures were to operate the furnaces at 3000 watts during the entire three-hour cycle. The new furnaces are expected to have an operational life of six months, as compared to two months for previous designs, providing element temperatures are not allowed to exceed $1000^{\circ} \mathrm{C}$.
\end{abstract}

\section{INTRODUCTION}

Wire-wound resistance furnaces are used at Rocky Flats Plant for molten salt extraction of americium from plutonium metal ${ }^{1}$ and for plutonium electrorefining. The requirements of the molten salt extraction process are that the furnaces melt 2500 grams of plutonium $\left(640^{\circ} \mathrm{C}\right.$, melting point) and 2500 grams of equal molar sodium chloride-potassium chloride- 6 weight percent magnesium chloride $\left(\mathrm{NaCl}-\mathrm{KCl}-6 \mathrm{wt} \% \mathrm{MgCl}_{2}\right)\left(670^{\circ} \mathrm{C}\right.$, melting point) in two hours and maintain the charge temperature at 700 to $750^{\circ} \mathrm{C}$ for one more hour.

Since measuring the salt temperature was inconvenient, the production procedure has been to run the furnaces at maximum power settings to insure melting of the charge. Furnaces have been failing after an average of 40 cycles, which is considered to be abnormally high. Thus, a decision was made to

\footnotetext{
1 J. L. Long and C. C. Perry. "Molten Salt Extraction of Americium from Plutonium Metal. Nuclear Metallurgy, Volume 15. Paper presented at Symposium on Reprocessing of Nuclear Fuels. Fidited by P. Chiottl. Iowa State University, Ames, lowa. August 25-27, 1969.

${ }^{2}$ J. L. Long and R. D. Schweikhardt. Plutonium Electrorefining at Rocky Flats. RFP-871. Rocky Flats Division, The Dow Chemical Company, Golden, Colorado. April 17, 1967.
}

determine whether these high power settings could be correlated to the furnace failures.

o t $3<-i$

An investigation of furnaces which had failed indicated that two modes of failure existed. Approximately 5 percent of the failures occurred at the stainless steel connection leiminals. These failures were caused by unsatisfactory connections between the terminal set screws and the element wire. In the remaining 95 percent, sections of the clements combined with the calcium aluminate cement to form a glass. Analysis of the melted areas showed that no foreign impurities were present. It was concluded that the furnaces had simply been operated at excessively high temperatures. (Furnace winding temperatures have been observed in excess of $1100^{\circ} \mathrm{C}$.)

The furnaces which failed were fabricated using 44 feet of BS-10 gauge Kanthal wire (Type A-1), and had a resultant surface area of 169 square inches (see Figure 1). With a power input of 3080 watts, the watt density was 18.2 watts per square inch. In Figure 2, watt density versus temperature plots (taken from the Kanthal Handbook) ${ }^{3}$ indicate that furnaces constructed from the Type A-l elements having a watt density of 18.2 watts per square inch will give only limted service at temperatures greater than $1120^{\circ} \mathrm{C}$. The graph of Figure 2 represents approximate values only. The actual permissible surface loading depends on construction of heating elements, the ceramic support, and the insulation, as well as the manner of operation.

The primary objective of the investigation was to fabricate and evaluate furnaces which would produce a significant increase in the number of heating cycles obtained without failure. In addition, tests were conducted to determine what minimum amount of power was necessary for the furnaces to attain a charge temperature of 700 to $750^{\circ} \mathrm{C}$ in two hours, and to maintain this temperature for one more hour.

\footnotetext{
${ }^{3}$ Aktiebolaget Kanthal, Kanthal Handbook. Kanthal Alloys for High Temperature Electric Resistance Matertals. The Kainthal Corporation, Amelia Place, Stamford, Connecticut. 1957.
} 


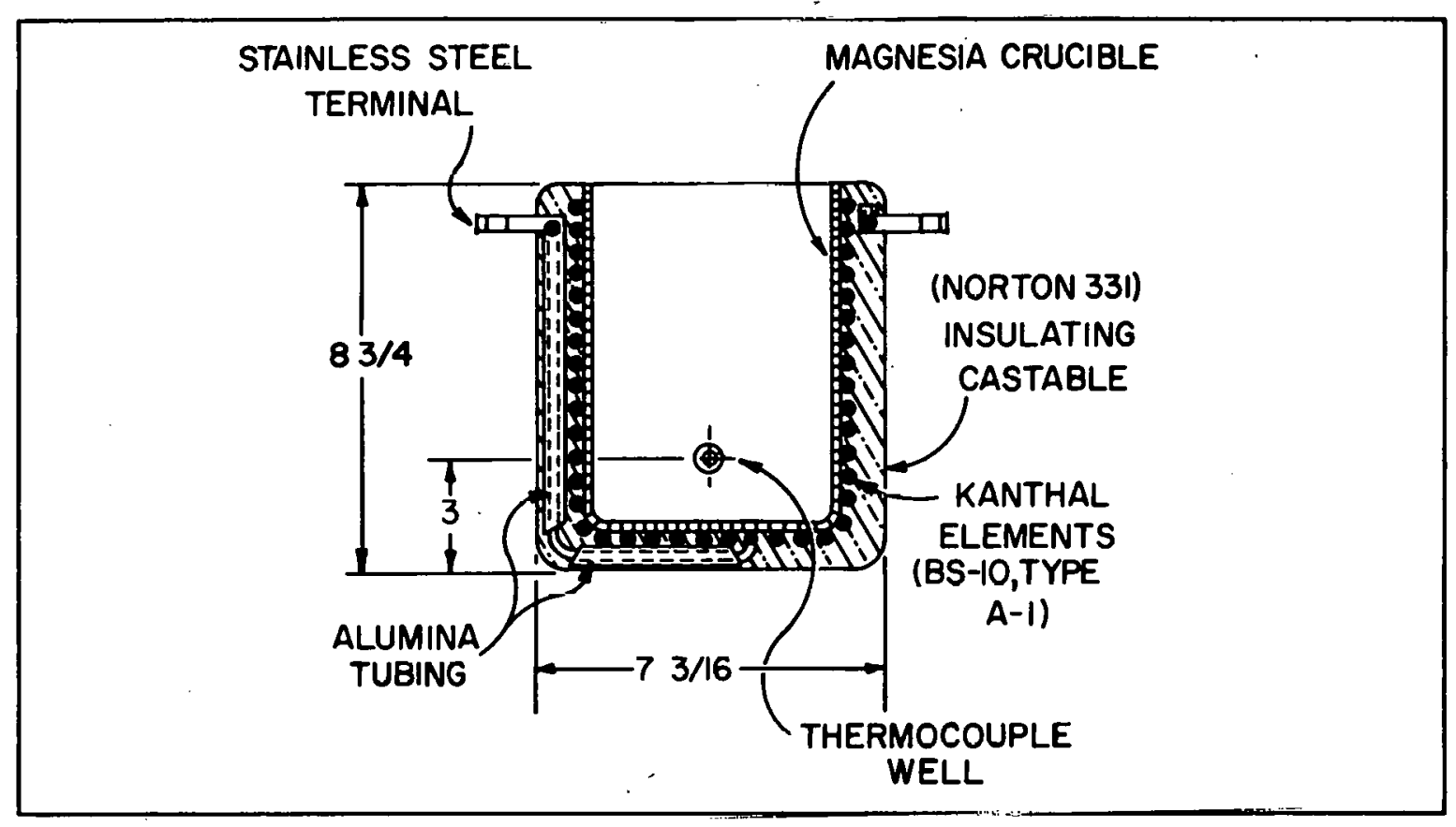

FIGURE 1. Gauge Resistanice Furnaces Which Failed in Production. (Inch dimensions.)

One way to obtain longer furnace life is to design the furnar.e. with elements which will operate at higher temperatures. Platinum elements will operate up to $1800^{\circ} \mathrm{C}$ in air. Platinum, however, was not investigated because it has several disadvantages when used in connection with the process. Because of the low resistance of platinum, some 175 feet of wire would be required for each furnace. Winding this much wire on a furnace would be physically impossible, unless it was wound into quarter-inch diameter coils. Platinum, expensive initially, would be even more expensive to recover if it became confaminated with plutonium.

Molybdenum elements will operate at temperatures up to $1800^{\circ} \mathrm{C}$, but must be operated in a reducing or inert atmosphere. To make such preparations would require substantial modification of existing cell equipment. Therefore, the decision was made to improve the Kanthal element furnace design.

\section{DISCUSSION}

Procedure: Techniques were developed for fabricating furnaces using BS- 8 and BS-9 gauge Kanthal Type A-1 wire. Basically, these designe conviutud of inereasing the element surl'ate area so that significantly higher power inputs could be used without exceeding watt-density recommendations.

A new furnaoo was fabricated using BS-9 gauge Kanthal wire. The furnace was constructed by spacing the elements with alumina beads on a collapsible model (see Figure 3 ). At 3000 watts, the furnace required 60.5 feet of 0.1144 inch diameter wire and had a watt density of 11.4 watts per square inch. The furnace has a maximum recommended element temperature of approximately $1225^{\circ} \mathrm{C}$.

The new BS-8 gauge Kanthal furnace designed for use at 3000 watts contains 76 feet of wire and has a watt density of 7.9 watts per square inch with a maximum operating (element) temperature of $1300^{\circ} \mathrm{C}$. This furnace is similar in design to the BS-10 gauge furnace, except that cotton string is used to space the elements $1 / 16$ of an inch apart. To fabricate the No. 8 gauge furnace, the elements are cemented to the crucible. with three strips of 50 weight percent calcium aluminate cemer and 50 weight percent minus 200-mesh alumina (see Figure 4). 


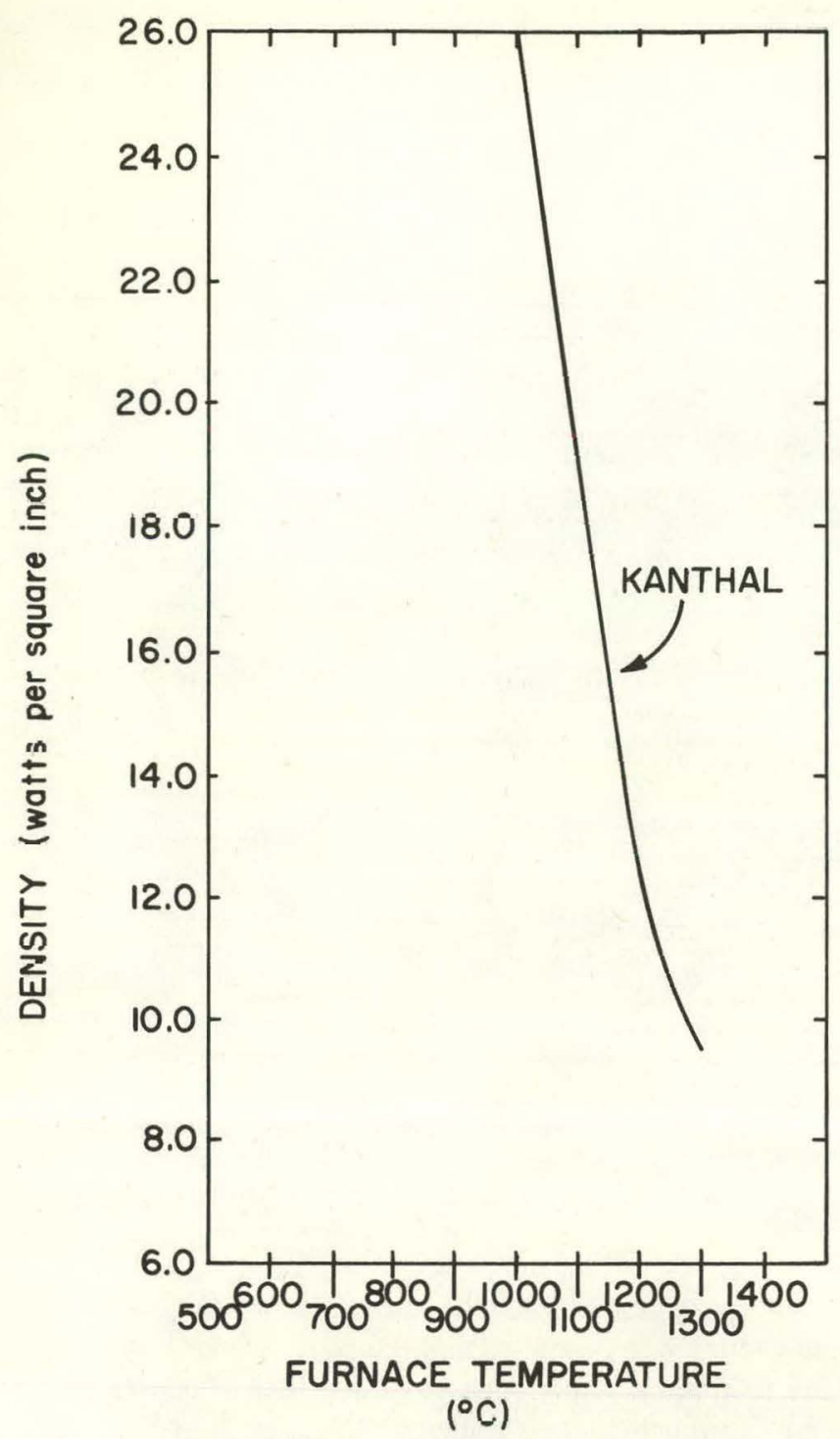

FIGURE 2. Approximate Maximum Surface Load for the Kanthal Type A-1 Heating Elements in Industrial Furnaces.

Atter the cement has cures, the sitring is cul and icmoved from between the elements. Ceramic beads were not used to fabricate the No. 8 gauge furnace because they require too much winding space.

To eliminate the terminal failure problem, new connection terminals were fabricated from Kanthal Type A-1 strip (see Figuıe 5). Thiese terminals were designed to produce a large contact surface between the clement wire and the connector. The large contact surface decreases resistance and allows the connector to remain cool during operation.

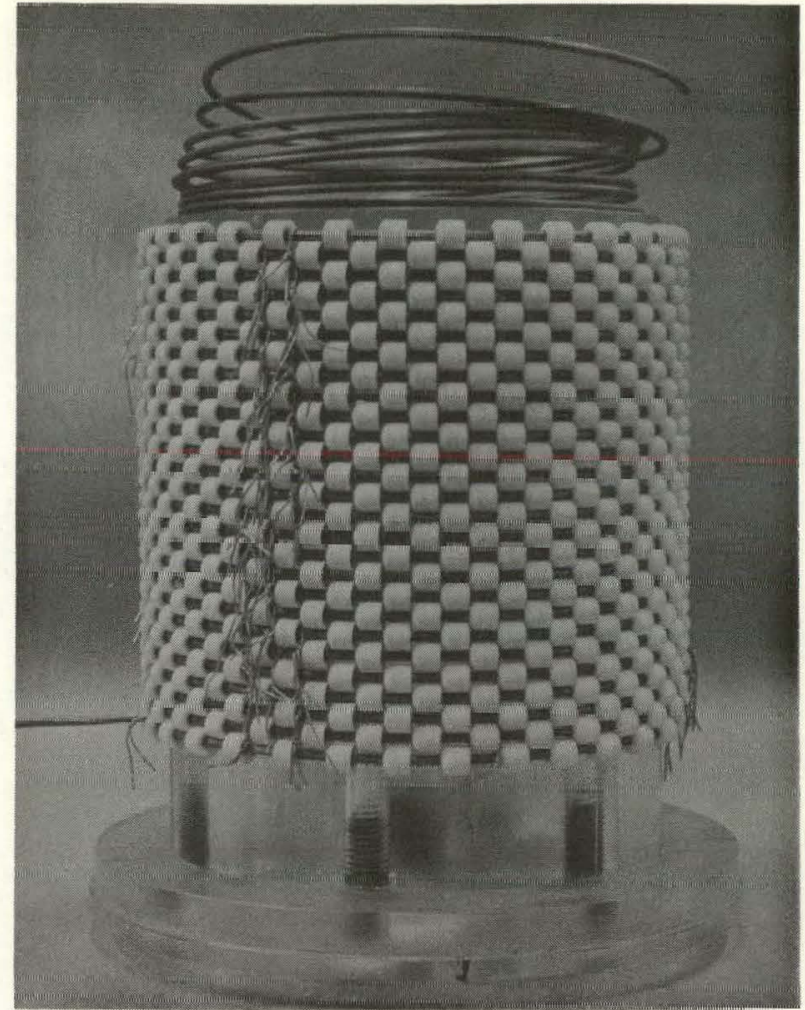

FIGURE 3. Alumina Beads and Lucite Model Used for Fabricating BS-9 Gauge Kanthal Furnace.

FIGURE 4. Construction of BS-8 Gauge Kanthal Furnace.

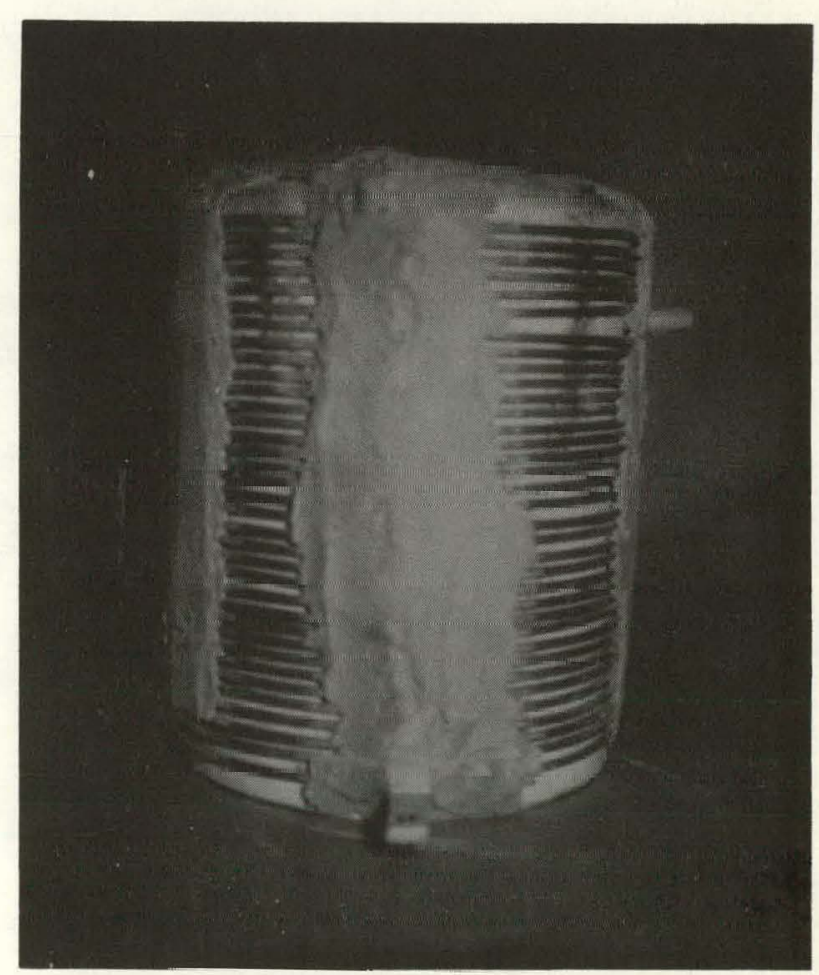



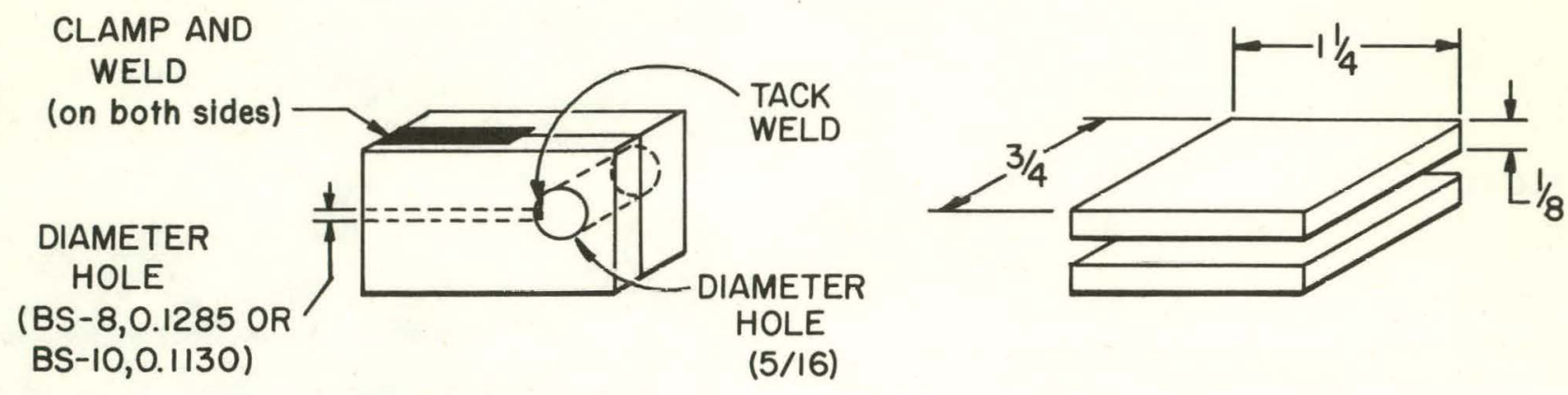

FIGURE 5. New Furnace Terminals Fabricated from Kanthal Type A-1 Strip. (Inch dimensions.)

The terminal is clamped and welded at the sides only. This eliminates wire embrittlement which occurs when the terminals die welded direcily to the elements.

The No. 8 and No. 9 gauge furnaces were cycled to $900{ }^{\circ} \mathrm{C}$ in two hours and held at temperature for one hour 124 and 154 times, respectively. Initial cycles used 3500-gram, mock-up salt charges to determine the power input required for maintaining a 700 to $750{ }^{\circ} \mathrm{C}$ salt temperature. This salt charge was used because it approximated actual operating furnace charges with respect to energy required for melting. The remaining cycles were completed using alumina grain as a filler material, in order to save the expense of salt cakes and stainless steel salt containers.

A production furnace assembly (Figure 6) was used to determine the power settings required to melt the 3500-gram salt charge in the cycle noted previously. During these tests, cooling water and argon flow rates were at 30 gallons per hour and 5 cubic feet per hour, respectively.

Results: After the cycle tests were completed, a visual inspection of the elements in the No. 8 and No. 9 gauge furnaces indicated no observable element deterioration. The use of the same power settings throughout the entire test program also confirmed the observation.

Cycles completed with the test-furnace assembly using argon and cooling water indicate that the furnace windings do not have to attain a temperature of greater than $900^{\circ} \mathrm{C}$ in two hours for the salt (3500 grams) to be at $700{ }^{\circ} \mathrm{C}$ (see Figure 7). Since the temperature was measured by a thermocouple not in direct contact with the elements, the furnace element temperature reading of $900^{\circ} \mathrm{C}$ is probably $50^{n} \mathrm{C}$ low. When the furnace temperature is held at $900^{\circ} \mathrm{C}$ for one hour, the salt temperature gradually increases to $720^{\circ} \mathrm{C}$. A power setting of 2700 watts was required to bring the furnace to $900^{\circ} \mathrm{C}$ and the salt to $700^{\circ} \mathrm{C}$ in two hours. These temperatures werc maintained for one hour by using a power input of only 1700 watts.

When the furnace assembly was at $900{ }^{\circ} \mathrm{C}$ and the full power of 3000 watts was applied, the furnace attained a temperature of $1000^{\circ} \mathrm{C}$ in 15 minutes. Thus if full power is used during the entire three-hour cycle, the elements will reach temperatures in excess of $1200^{\circ} \mathrm{C}$ and burn out. In order to obtain a long furnace life, reducing the power settings becomes necessary af the element temperature is at $900^{\circ} \mathrm{C}$. 


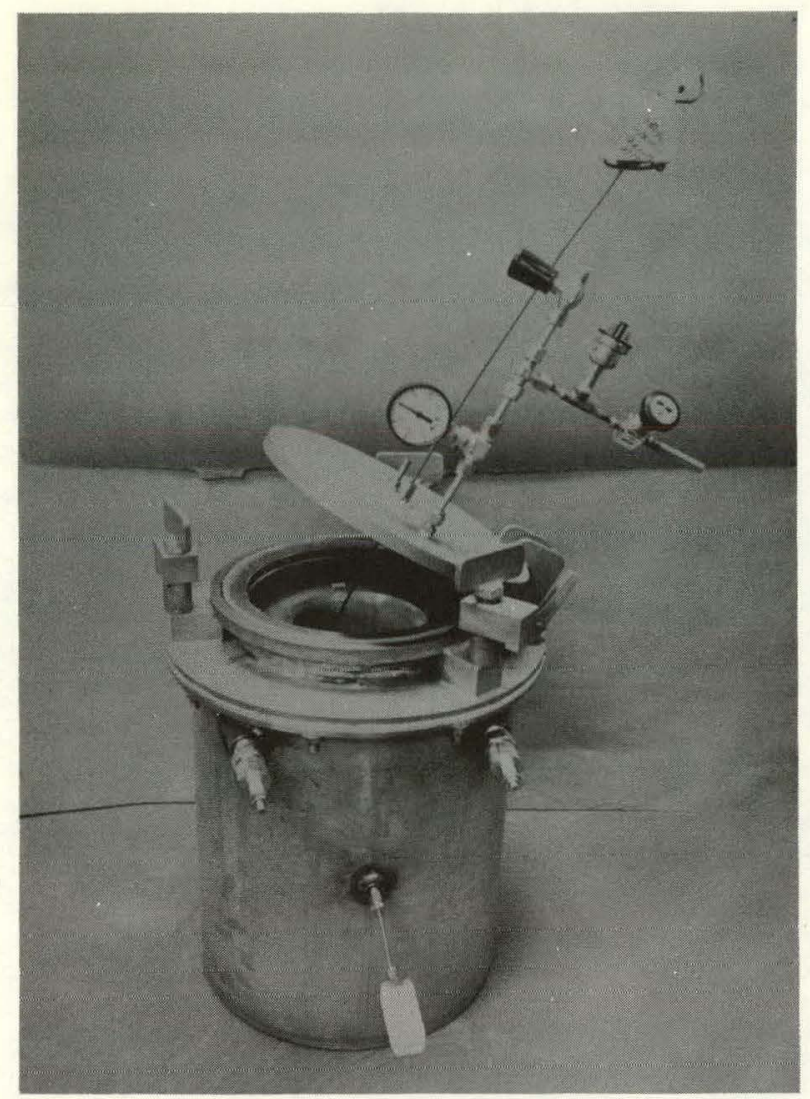

FIGURE 6. Test Molten Salt Extraction Assembly.

The estimated costs for fabricating the new furnaces are given in Table I. These costs are based on a labor rate of $\$ 10$ per hour, which would approximate commercial vendor rates. Tooling costs would be approximately $\$ 50$ for the No. 8 and No. 10 gauge furnaces, and $\$ 250$ for the No. 9 gauge furnace.

\section{CONCLUSIONS}

Two new furnace designs utilizing Kanthal Type A-1 elements have been fabricated and successfully tested. These furnaces have a greater margin of safety with respect to operating temperature and should have an a operational life in excess of six months, as compared to two months for previous designs. The time period will be seriously reduced, however, if indiscriminate power settings are used, which produce element temperatures in excess of $1000^{\circ} \mathrm{C}$.

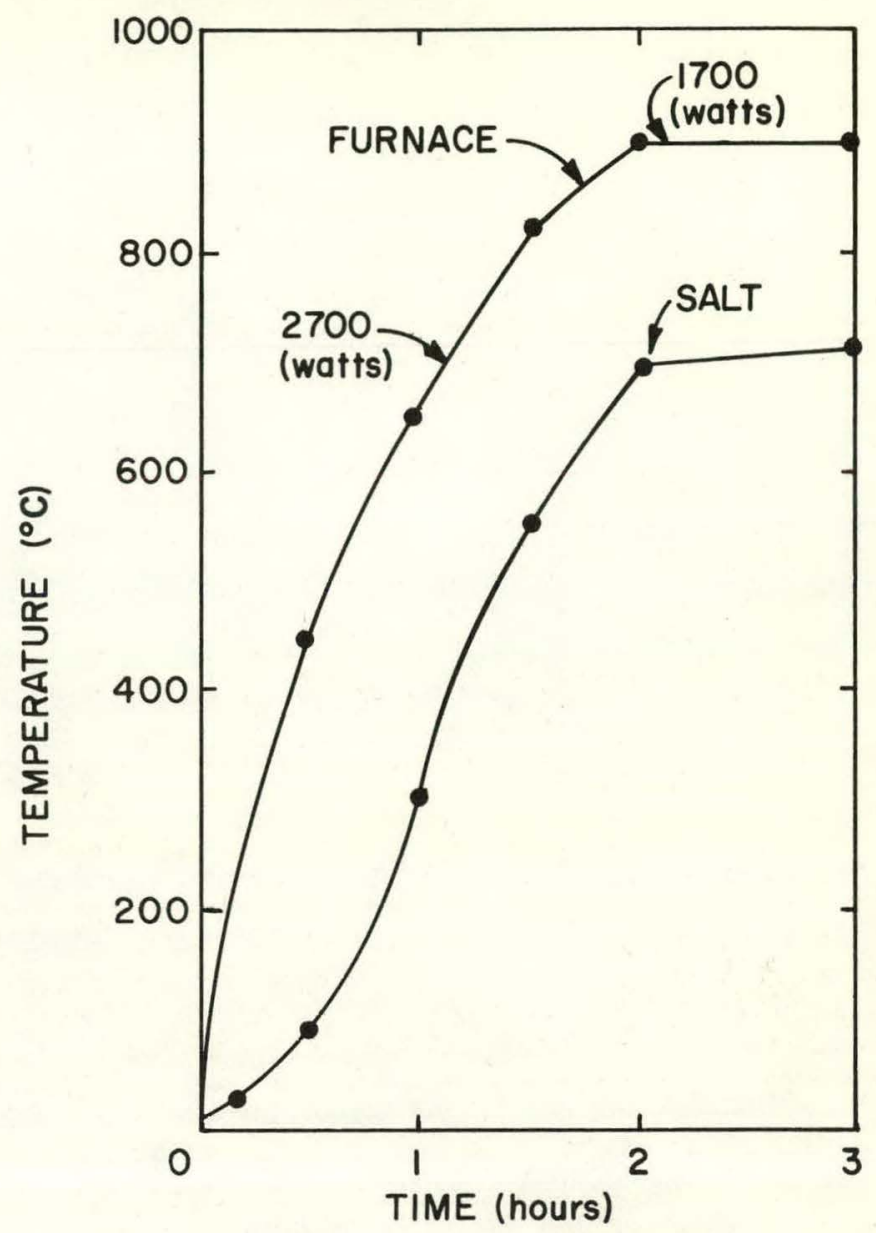

FIGURE 7. Typical Furnace Cycle for 3500-Gram Salt Charge.

TABLE I. Estimated Costs for Fabricating Kanthal Furnaces.

BS No. 10

BS No. 9

BS No. 8

Kanthal Wire
(Type A-1)
Calcium Aluminate Cement
Alumina Beads
Alumina Tuhing
"Norton-33I Castable
Magnesia Crucible
Labor
(\$10 per hour)

4.00

5.00

6.00

1.00

$-$

2.00

40.00

100.00

100.00

1.00

77.00

2.00

40.00

$-$

240.00

1.00

$-$

2.00

40.00

100.00

140.00

$\$ 247.00$

$\$ 365.00$

$\$ 289.00$

"Nurtun Company, Refractories Division, Worcester, Massachusetts. 